\title{
E-Business Development and the Factors Affecting of its Application in Hospitality Operations Sustainability
}

\author{
Irwan Ibrahim ${ }^{1}$, Muhd Feisal Ismail², Afizan Amer $^{3}$, Farrah Nadia Baharuddin ${ }^{4}$, \\ Mif Rohim Noyo Sarkun ${ }^{5}$ \\ Malaysia Institue of Transport, MITRANS, Universiti Teknologi MARA, \\ Shah Alam, Selangor, Malaysia ${ }^{1}$ \\ Universiti Teknikal Malaysia, Melaka, Malaysia ${ }^{2}$ \\ Universiti Teknologi MARA, Rembau, Negeri Sembilan, Malaysia ${ }^{3,4}$ \\ Universitas Hasyim Asyari, Jombang, East Java, 61471, Indonesia ${ }^{5}$ \\ \{irwan623@.uitm.edu.my11,feisal@utem.edu.my²,afizanamer@uitm.edu.my³, \\ farrahnadia@uitm.edu.my ${ }^{4}$,mifsyarkun@gmail.com ${ }^{5}$.
}

\begin{abstract}
Digital technology has become an essential catalyze for the tourism industry. Digital technology played a significant role in shifting the tourism sector into an impact driven industry. Factors affecting the usage of E-business in the tourism industry have been well-documented in developed countries, but further studies are needed to investigate the usage of E-business in the tourism industry among developing countries. This study aims to identify the level of Ebusiness usage as well as the benefits and barriers of E-business adoption in hospitality operation sustainability among local tourism agencies operating in Melaka. The E-Business Measurement Evolution Model and the quantitative approached was applied for this study. Questionnaires were distributed to the respondents in the form of an online and self-administered questionnaire. Statistical Package for Social Science (SPSS) version 25.0 was used to analyze the data. The research findings revealed that tourism agencies in Malacca were still in the early stages of E-business usage, with only (54\%) of the travel agencies are online. The factor of saving time $(\mathrm{M}=4.3492)$ was the key benefit in E-business usage while the factor of hackers' intervention $(\mathrm{M}=3.8730)$ was revealed to be the most deterring factor that causes the tourism agencies reluctance to adopt E-business practice. This study shows that government aims of E-business tourism have not been fully realized. The respondents still perceive the factors of internet fraud and security are a significant issue for Ebusiness usage. Therefore, future research is recommended to provide more insights into the application of E-business tourism in tandem with the government aim of the hospitality operations sustainability Malaysian tourism industry.
\end{abstract}

Keywords: E-business Measurement Evolution Model, Sustainability, Tourism, Digital Technology 


\section{Introduction}

The Malaysian tourism industry started with the establishment of the Tourist Development Corporation (TDC) in 1972. Today, small and medium-sized enterprises (SMEs) in the current period of tourism is referred to as the era of " complete electronic phenomena, " as several electronic phenomena have been introduced for businesses, citizens and government such as electronic banking, e-commerce and electronic life.

According to [1], argues that the way of Internet communication range allows easy monitoring of customer needs and expansion and adjustment of the business strategy with the most root form such as email service, newsgroups and chat-room participates. Andy Grove, Intel's chairman and co-founder, "The world now runs on Internet time. Don't waste time if you want to keep pace, act now to 'e"' he said. Therefore, [47], view that the adoption of ebusiness is firmly linked to the innovation for increased use of the Internet now become a business medium that inspires companies to explore another method of serving their customers. Thus, the implementation of information technology and communication (ICT) bring fundamentals of competitiveness and economic growth for companies, organizations and countries [55]. The impact for ICT application gives organizational changes in service firm [43]. Malaysia ranks 31st among the most tech- ready countries in the world which has 146 per cent mobile access, 22 million Internet users, 18 million active social media users and 7 million online shoppers [59].

Unfortunately, the adoption of e-commerce which is a subset from e-business [35] still limited due to different features and attributes compared between with SMEs and large organizations [75]. Many companies just sell their products by embrace Facebook pages [9]. Besides, the lack of awareness about benefits and barriers among SMEs makes the use of technology not properly [25]. The e-business adoption technologies by SMEs into their business processes was also due to influence factors such as innovation company characteristics [50].

According to [68], Malaysia is a multiracial population and having a balanced market size and expansion that will be as a good example point for Southeast Asia countries. In another word, Malaysia is a good reference for the research of e-business among developing countries. Hence, the aim of this study was to explore travel agencies in the tourism sector in Malaysia for the adoption of e-business from the perspectives of the level of adoption framework as well as investigate the benefits and barriers.

The tourism industry is considered to be the 3rd highest contributors to economic growth in Malaysia [64]. Besides, the number of travel agencies registered with the Ministry of Tourism Malaysia increased by 5.6 per cent in 2015. Therefore, [38] interested and increased of the tourism sector by launching [38]. Travel to give a convenience service to the tourist in the online travel market. Nowadays, most SMEs in tourism take e-business as their main business platform. They use social networks, e-mail and websites assigned to promote their services such as accommodation, travel agency, food service, transport and leisure services reported by The SMI Association of Malaysia (Small and Medium Scale Industries). Moreover, Malaysia also reported as a high level of digital adoption as a whole (Giap et al., 2016 [58]. In 2017, there are 24.6 million Internet users in developing countries use the Internet, representing 78.3 per cent of the population and 22 million are Facebook users (Internet Worldstats, 2017).

Despite the rise of the internet and the rapid adoption of e-business, tourism sectors are still underdeveloped areas. There is a small proportion of companies pursuing deep digital adoption [58]. Malaysia's technological revolutionary movement in travel agencies has not 
improved its online booking systems and only one-third of which are travel agents working on e-commerce sites [8]. In addition, Malaysia SMEs travel agencies continue to rely on a conventional business approach, although they recognize the advantages of e-business. Travel agencies experiencing a poor rate and slow in adopting web-technology and e-business adoption [51]. Deputy International Trade and Industry Minister encourage SMEs to be prepared to adopt digital technology in their efforts to access global markets such as ecommerce because of it 13 times faster than the business traditionally [67]. Furthermore, the use of information communication and technology (ICT) for online business transactions (ecommerce and e-business) among Malaysian small and medium-sized enterprises are still rare and little focus on comparing with a large organization. According to [54], e-business or ICT adoption is still relatively low only $19.6 \%$ of SMEs are involved in doing business online and $80.4 \%$ did not sell product or service online. Most respondents run their businesses using electronic devices but still low in using ICT tools service.

The National ICT Association of Malaysia (Pikom) has announced that it has signed a Memorandum of Understanding (MoU) with [38] to help achieve its objective of promoting the adoption of e-commerce between small and medium-sized enterprises (SMEs) in the country. Thus, in order to be more competitive in a business of travel and tourism and in parallel with government initiatives to develop human intellectuals. Strengthen and enhance the business performance of travel agencies by adopting ICT it is important to diverge Malaysia's knowledge-based economy from its competitive economy. Due to the positive growth of the business of travel agencies through the use of ICT and the increase of competition in the global environment, it is worth making sure that e-business is applied and adopted in today's business practice. Therefore, in order to understand and meet the travelling needs of modern tourists, it is essential to analyze the current demographic profile and application of e-business with the current advantages and barriers of Malaysian travel agencies in contributing to the implementation and transformation.

\section{Literature Review}

The adaptation of the Internet and World Wide Web (www) technology had given new term for businesses during the past 20 years. The term e-business which transforms from a traditional business into e-business in the year 1996 had begun to spread and influence rapidly in industries. The issue of emerging e-business market has been accumulated every year and it is considered as one of the vital tools in increasing the sales and revenue for company growth. However, there are still some preconception and obstacle for the adoption of this new approach. The target of this study is tourism SMEs in developing countries such as Malaysia. Besides, the explanation from divergent authors of this term will be appointed in examining the adoption of e-business. SMEs need to understand both the benefits to be gained and the obstacles to be resolved when attempting to participate in electronic market strategy. This section of the paper discusses the literature of research and determine the benefits and obstacles.

\subsection{E-Business}

E-business is an acronym for electronic business which is generally known as a business that been process electronic and digital or online business. The transaction business via the 
internet which is also a business model that able to exchange information and services between buyers and sellers [2]. This view is supported by [34] who write that the e-business concept encompasses possible uses technology of communication and information. In simple words, the buyer and seller do not need to meet personally to do business. E-business is considered to use technology to increase business processes that include internal process management, such as human resources, financial and system of administrative and external processes such as marketing and sales, the supply of goods and services and customer relations [13]. The adoption of e-business can be described as a situation in which a company is ready to accept technology innovation and transform its current business operations and business vision.

Due to electronic development, e-commerce is seen as a slice of e-business [15]. The first generation of e-commerce primarily involves trade, e-service and corporate cooperation. Currently, moving to e-commerce 2.0 based on web 2.0 tools, social media, social network, and the virtual world [66]. Yet, [49] point out that the term of e-commerce and e-business are interchangeable due to the changing of computer-based information systems and networks. However, e-business is a much wider scope that e-commerce according to the IBM outline term of e-business back than in 1997 as:" the transformation of key business process through the use of internet technologies" [15]. In addition, according to [15] new label for e-business is a digital business. The example of e-business communication such as e-mail, social media, website and e-commerce

\subsection{Level of E-business Adoption}

The business model can be measured by the level of e-business adoption. The construction of a business model for role and characterization of the various corporate actors [62]. Ecommerce model is a business mechanism which money flows and goods while e-business model is a mechanism for identifying strategic business objective [6]. All business models used in practice focus mainly on offering value and generating revenue through e-business structures. Besides, all models usually have an information processor, information insight and the outcomes that are predicted to improve the understanding of the framework.

The use of information systems in organizations has often been described as "stages of growth models" [16]. Richard L. Nolan developed the first stage model back in 1973 called stages of computer budget growth consisting of four stages (Stage 1: Initiation, Stage 2: Contagion, Stage 3: Control, Stage 4: Integration) when information technology is blooming. Then in 1979, Richard L. Nolan added another two stages to his proposed model to complete his six-stage model (Stage 1: Initiation, Stage 2: Contagion, Stage 3: Control, Stage 4: Integration, Stage 5: Data administration, Stage 6: Maturity). Since then, other studies have developed and suggested that organizations undergo growth stages in their adoption of ebusiness [42],[61].

Several researchers utilize e-adoption model for procedure step that begins e-mail communication and then with the basic website, e-commerce and e-commerce until the transformed organization. The view of the Department of Trade and Industry (DTI) adoption ladder in Figure 2.8 was among the most infamous models in the UK government around the 1990s [42],[61]. Research embraced in the United Kingdom for the Department of Trade and Industry (DTI) distinguished an "adoption ladder" for SMEs as they built up their online plans of action, shown in Figure 2.8. This conveys how small enterprise progress in adopting ICT and support to understand the depth of e-business. That is stage 0 (non- adopter) imply that the company does not have entry to the Internet. Stage 1 (Emails) company imply the Internet for 
information and communications via e-mail but have no website. Stage 2 (Websites) company has websites that contain simple business information and still require additional information from customers. Stage 3 (E-commerce) where the website is no internal connect to systems and access to obtain a more detailed product or service information and pay through website services. Stage 4 (E-business) execution, order processing, marketing and accounting embedded with other business systems by the online shop. Stage 5 (transformed) Internet technology control all processes of the internal and external business.

\subsection{Definition of Small-Medium-Enterprise and Tourism}

The term " SMEs" refers to " small and medium-sized enterprises." The exist of SMEs are several definitions and meanings. According to [5], claims that SMEs is hard to define in a single term for global use because it reflects the criteria of the countries itself. Elsewhere, [17] view that the country, industry, size and employment is considering different which make the main cause of vary SME definition. According to [44] highlighted that SMEs is a creating process from entrepreneurship. Figure 1.0 is a new definition for SMEs by [54], the sales turnover manufacturing sector not surpassing RM50 million or full- time staff not surpassing 200 employees. Continue for services and other sectors with sales of no more than RM20 million or full- time staff of no more than 75 employees.

The World Tourism Organization (WTO) suggested in 2002 that promoting tourism in developing countries is a massive advantage for the poor [18]. In 2018, World Tourism Organization (WTO) reported the advanced economies of Americas, Europe Asia and the Pacific were the world's leading international tourism source markets. However, emerging economies such as Africa, Asia, Central and Eastern Europe, the Middle East, and Latin America have shown rapid growth driven by rising levels of disposable income.

In additional, SMEs represent a principal driving force of economic growth and in nature are closely related to the tourism sector. The activities of travelers on journeys outside their usual environment for a period of less than one year is defined as travel and tourism [69]. The tourism industry offers relatively easy entry for SMEs with low capital requirement and operated at low cost [18]. Moreover, characteristic of tourism sectors such as travel agents, airlines airports, hotels and leisure and recreation services that deal directly with tourist [69].

\subsection{Age and Organization Involvement in Hospitality Operations Sustainability}

Malaysia continued to gain international recognition and for the second year in a row was named Asia's leading destination at the Asia and Australasia [69] and third year in a row for World Top Muslim Friendly Destination No. 1, according to [39]. At the [65], the country also won the Best Asian City Destination and Best Asian Culinary Destination, while in 2016, Kuala Lumpur was among the top five destinations on the World's Best Shopping Destinations list in [64]. Furthermore, George Town was listed in the top 10 cities of Lonely Planet for Best in Travel 2016, while Ipoh was listed in Lonely Planet's top 10 best in Asia 2016 [19]. Gross domestic product (GDP) produced by industries dealing directly with tourists, e.g. IT services from travel agents, purchases of food and cleaning services from hotels, fuel and catering services from airlines and, hospitality, food and beverage, transportation, and retail and attractions are the key tourism sub-sectors.

Tourism Malaysia Integrated Promotion Plan for 2018-2020 key markets revolve around forming strategic partnerships with airlines and corporate bodies, utilizing digital media platforms for marketing and publicity, organizing fam trips for selected markets, and taking 
part in major international tourism trade shows. In line with its objective to intensify the use of digital marketing, tourism Malaysia has signed a Memorandum of Understanding (MoU) with Alitrip, an Alibaba Group owned e-commerce platform, to further promote China [11]. According to the 2016 economic census, tourism statistics generated revenue of RM147,3 billion for the tourism e-commerce industry. In terms of contribution to retail trade (shopping) services, the highest percentage was $46.6 \%$ followed by air passenger transport (17.4\%) and sports and leisure services (13.0\%).

Adoption of digitization has reflected for all tourism, travel, hospitality and catering industries processes and value chains [14]. Since e-commerce plays a unique role in contemporary SMEs [31] it is vital for Malaysian tourism to equip themselves with the application of e-business to guide for a clear understanding for adoption trends and successful business. Moreover, the industry can expand its distribution channel and dramatically expand its value chain as a way forward for many destinies by embracing new and innovative business models [14]. However, the use of e-commerce by tourism SMEs in Malaysia is still in its infancy [26]. According to [50] Malaysia tourism SMEs still far achieving e-commerce level adoption. Yet, e-commerce adoption among small and medium enterprises (SMEs) is expected to grow to $50 \%$ by 2020 from $32 \%$ in 2016 , driven by the sector's increasing interest in online business [60].

\subsection{Benefits of E-business Adoption}

E-business gives an optimistic change for SMEs in this new environment business yet the level of adoption is still low [28],[48],[31],[26] This is because of the lack of knowledge about the benefits that the technology will provide to SMEs [23] and impracticable perception toward the change of business work [48]. According to [56] the benefit of entering e-business is same with the benefit of entering the e-marketplace, access to a wider range of markets, increased partnership potential, management flexibility, communication, convenience (24/7 accessibility), improved customer service, updating information, product and service differentiation, less cost of transaction, and ability to enter for big companies supply chain. It takes time for SMEs to relies on the extensive benefit of participation in e-marketplace [56]. Besides, [56] mention the need for SMEs to understand the benefits of e-marketplace environment to make the application of e-business adoption more valuable. However, identifies emerging to the global market will be cost effective for the transaction and wider market range [32], [26].

Therefore, [31] and [50] argues that adopting the e-business will reduce cost for not only transaction but also marketing and advertising, increase return on investment (ROI), enhance corporate image company brand, increase end-user responsiveness and accessibility, improved efficiency and flow of business processes, improved customer service, increased market share, increased profit, productivity, customer loyalty and retention. In his major study, [31] discuss the benefit of adopting e-business in the perspective of SMEs in Malaysian and Indian is primary on the enhanced company brand and corporate image due to gain customer trust. In other word, SMEs invest heavily in branding and market positioning to maximize their benefit from the application of technology, followed by lower costs and improved customer service. According to [26], the benefit for adoption was improved customer service due to improving communication, increased speed and efficiency from supplier to customer.

Claim that with a border market enter range have reduced an additional cost for marketing champagne to the potential and also will improve the relationship between supplier and customer with lower transaction cost and increased profit because of the trusted gained [12]. 
Furthermore, [4] lists six most benefit of adoption benefits from increased competitiveness, improved customer service, increased sales, increased access to a wider range of markets, improved distribution channels, increased communication flexibility with business partners which supported some analysts of [12]. On another hand, SMEs have reduced cost and generated a lot of profit by cutting an advertisement cost to reach customers.

\subsection{Barriers of E-Business Adoption}

However, despite the perceived advantages, there are also been numerous constraints to be aware of maximizing e-business adoption. Most of SMEs have been slow to adopt e-business and face a lot of competition neither the offline market nor online market [32]. The common factors that assist in barriers of e-business such as enabling factors, cost factors, security and trust factors [41]. SMEs does not feel fit for adopting e-business in the current mix of the customer [41], [33]. According to [29] argues that security issues become a major issue as the customer find Internet transaction is not safe and preferred traditional method for a business transaction to avoid fraud. According to [33], the main concern is the lackness of security payment such as credit card along with lack of privacy by spreading confidential detail over the internet and hacker intervention that illegally access to their company computer that becomes the major barriers of adoption. The preliminary work on [33] was undertaken by [7]. He stated that the lack of security still become the barrier concern in the studies Malaysia context but the top major barrier shifting to a high-cost startup. Highlights the technological appliance is an expensive cost for e-business set-up because of the maintenance that needs to do [7]. For example, initial costs of creating, hiring and purchasing for websites, Internet services to operate e-business technologies [29].

Reported that high implementation of the cost associated begins the top five barriers in ebusiness adopting [4], [7]. The claimed been supported by [30] because there is uncertainty positive result toward the investments on software and technology thus there still of trust issue because of the clients still prefer to receive an invoice and pay by bank transfer rather than online transfer. This view is not supported by [2] who find that there is a lease concert of the high cost of internet connectivity and websites for the barrier in the SME context. Besides, SMEs leaders in e-commerce find a low barrier to development and maintenance systems of ebusiness because they are more interested in boosting their revenues by using e-commerce rather than concerned on costs adoption [41].

Identifies corruption, lack of popularity for online business transactions, lack of electricity, low level of literacy among SME owners and lack of developed legal and regulatory systems as the major causes of barriers adoption [2]. Supported [22] data in term on lack of electricity and lack of legal and regulatory system, yet another barrier such as shortage of energy, lack of capital and security issue has been cited as key challenges prevent e-business adoption and development.

\subsection{Theoretical Framework}

The study aimed to measure activities of e-business adoption in Malaysia travel agencies that begin the test by adopting an E-business Measurement Evolution [2] The Figures 1.0 shows research model framework consisted of the dependent variable for this research is the level of e-business adoption, while the independent variables are the company's profile, barriers of e-business and benefits of e-business. 


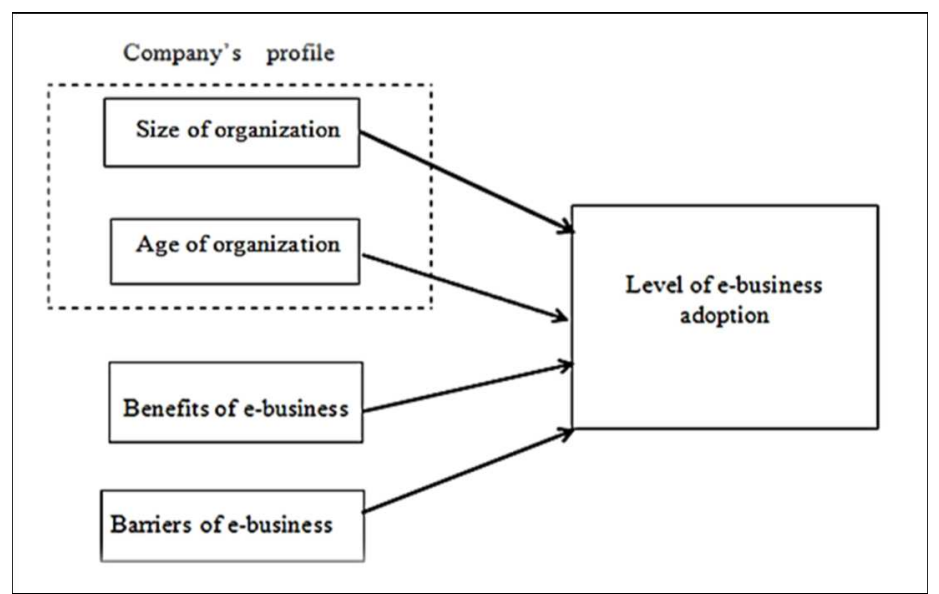

Fig. 1. Research model framework (Source adapted: [50],[2])

\section{Result and Discussion}

\section{a) Hypothesis 1}

There is a significant relationship between size of travel agencies and level of e-business adoption. In this study, it is shown there is a relationship between the size of travel agencies and the level of e-business adoption. The Pearson correlation and $\mathrm{R}$ and Beta value from the simple regression show the value is 0.370 . The result shown in both correlation and simple regression method is the significant and p-value is 0.003 which according to [52] said the relationship between the variable was clear and significant.

The result is soundly supported by [63] which state that the impact of adoption depends on firm size. Besides, [27] had argued big companies tend to adopt more technology to their companies rather than the small one. Moreover, according to [10], there is a positive and significant relationship between travel agency size and the adoption level of e-commerce. So, it can be clearly seen that travel agencies size significantly affects the decision to adopt ebusiness in this study. Thus, hypothesis 1 is accepted.

\section{b) Hypothesis 2}

There is a significant relationship between age of travel agencies and level of e-business adoption. In this study, it is shown there is a relationship between age of travel agencies and the level of e-business adoption. The Pearson correlation and $\mathrm{R}$ and Beta value from the simple regression show the value is 0.257 . The result shown in both correlation and simple regression method is the significant and the $p$-value is 0.042 which $p<0.05$ which mean there is a significant relationship between the age of travel agencies and level of e-business adoption. Thus, hypothesis 2 is accepted.

The result was consistently supported by finding that the age of the organization has a significant relationship with e-business adoption [37],[45]. Furthermore, [57] have shown that the greater a company's ICT capability in terms of facilities, the greater the probability of ebusiness implementation which means the more employee in organization mean the more change will be made. This can be also concluded as the more company sustain and experience 
in the industry, the higher change will be implemented.

\section{c) Hypothesis 3}

There is a significant relationship between e-business benefits and level of e-business adoption. In this study, it is shown there is a relationship between e-business benefits and level of e-business adoption. The $\mathrm{R}$ and Beta value from the simple regression shows the value is 0.052 . However, the p-value consisted of 0.688 for both correlation and simple regression method that $p>0.05$. This shows that there is no relationship and no significant relationship between e-business benefits and level of e-business technology. Thus, hypothesis 3 is rejected.

Thus, the research did not discover the statistical importance of the relationship between benefits and level of e-business adoption that result supported by [2]. This result addresses the prior research [4; Inanov, 2012 [26],[50] discovered it is significant between e-business factor influencing e-business who argued that e-business is capable of delivery benefits but the benefits factors need an embedded whole change of aspects to gain technology adoption. Surprisingly, this study outcome violates many of the results of past research, which discovered that the benefits factor is not related to influence the level of e-business adoption. Based on this finding the study concludes that travel agencies in Malacca are conscious of the benefits of using e-business, but the adoption level e-business in each travel agency not the implementation from e-business benefits.

\section{d) Hypothesis 4}

There is a significant relationship between e-business barriers and level of e-business adoption. In this study, it is shown there is a weak relationship between e-business benefits and level of e-business adoption. The $\mathrm{R}$ and Beta value from the simple regression shows the value is 0.188 . However, the p-value consisted of 0.140 for both correlation and simple regression method which $\mathrm{p}>0.05$. This shows that there is no significant relationship between e-business barriers and level of e-business technology. Thus, hypothesis 4 is rejected.

There are many previous studies identified the significant barriers for technology adoption [28]; [56]; [40]. However, [24] reported that the barriers between companies to adopt ebusiness technologies have not yet been untangled. Moreover, [63] reported questionable whether these obstacles have an important impact on the decision-making or development stages of e-business techniques. The main text for your paragraphs should be 10pt font. All body paragraphs (except the beginning of a section/sub-section) should have the first line indented about $3.6(0.14 ")$.

\section{Conclusion}

As a decent business medium, the fast spread of the Internet has raised the awareness of the digital business, which has led SMEs to invest in various kinds of e-business technologies. However, gaining advantages from adopting these techniques are not as simple as SMEs need to resolve many obstacles connected with their application. Although the attitudes of SMEs regarding advantages and obstacles are reported in some literature, prior studies have less differentiated among Malaysian tourist organizations. In specific, little was explored from the view of travel agencies providers. The main objective of conducting this study are (1) to determine the level of e-business adoption among travel agencies, (2) to identify the benefits 
of using e-business among travel agencies and (3) to investigate the barriers of using ebusiness among travel agencies.

The findings of this study show that there were only four levels of e-business adoption by travel agencies in Malacca. Namely, e-mail stage, social media stage, websites stage and ecommerce stage. The result of the study shows that the current level of e-business adoption was most applied at website stage. However, the researcher does agree with [46] and [36] that travel agencies do not create and retain their own website as much as possible as an informative website. This is because according to [21], social media cited that a lot of customers use social media as a platform to buy the product which leads most of the travel agencies were actively focus on social media platform such as Facebook to sell their service and just make a website for a validation purpose only. Besides, this shows that all Malacca travel agencies were connected with the internet for their daily business activities. Yet, Malacca travel agencies still not common with an advanced level of e-business technology adoption which none of the travel agencies had applied or use of mobile apps, cloud computing, e-business and transformed organization. Moreover, the organization size and age been considered as a driver for the increase stage of e-business adoption which is a significant relationship between the size and age of travel agencies and adoption e-business level finding were found. Furthermore, more travel agencies cited that hacker intervention, lack of IT personnel, lack of privacy, lack of security and reliability of systems and high cost of internet connectivity and ICT equipment as comprehensive series of difficulties in e-business adoption. Besides, the study found that there was no significant relationship between barriers to the adoption level of e-business. However, the finding of [10] and [3] argued that there was a significant relationship between these two variables. The increase in the level of e-business is affected by barriers. Same goes to that barriers will deter of increasing level of adoption. This can be concluded that travel organizations are prepared to embrace a higher standard of ebusiness if they have more safe information security and an adequate budget for e-business execution, retention and staff preparation.

Nevertheless, those who have embraced e-business platforms have been discovered to appreciate certain advantages. These benefits range from save times, improved customer services, easy and fast exchange of document and information. Also, it makes travel agencies owner or managers have a wide range of market entry as well as increase flexibility in communicating with business partners within the tourism industry. In a nutshell, the study found that there was no significant relationship between the benefits of travel agencies and the adoption level of e-business in travel agencies in Malacca. However, the researcher agreed with the outcome of finding violates many of the results of past research. The advantages affected all levels of e-business acceptance among Malacca travel organizations, which means that it is more comfortable for travel agencies to observe the advantages of e-business acceptance by other adopters a before applied own organizations. Overall, the increased level of e-business adoption in tourism industry required participant of owner/manager and government in designing strategy for the company in order to put ICT as one of the priorities that people will consider in using e-business in business activities.

\section{a) Implication of the study}

This section will indicate how the findings may be crucial for strategy, practice, theory and later studies for travel agencies and government to consider when adopting e-business. First, the findings of this study provide a useful structure and would inspire and give understanding for travel agency decision maker to improve their e-business acceptance decisions to introduce 
a digital data systems approach. The decision maker can direct define the phase of e-business that could be helpful for their company by assist draw up a roadmap and plan to extend their company technology.

Even though, the government have a lot of law and regulation protection about using ebusiness such as the Personal Data Protection Act 2010, Digital Signature Act 1997 and Malaysian Communications and Multimedia Commission (MCMC). Yet, the finding main barriers concern of travel agencies is still hacker intervention. The result gives current information for the government to create and promote awareness of e-business adoption among travel agencies. By organizing many activities and programs such as talk, digitalization exhibition to ensure the e-business technology is encrypted with the safety advice and safe booking deposit information and also well fitted with safety tools to provide all data transferred over the computer to SMEs. Next, create a new policy. The government should liberalize the telecommunication sector, lower taxes and tariffs for quivers like pc, servers, switches and routers, which may ramp up e-business adoption because most travel agencies were in the small-companies category which concerns on the cost of operating.

\section{b) Limitation and Recommendations}

The limitation of the study was a small sample, time and cost. To increase respondent's response by hand distribution, need to match with travel agencies working hours that takes a lot of time to distribute. Another than that, when the distribute of questionnaire whether in manual or digital, both had the cost need to obtain. For manual distributed, the researcher needs to print the questionnaire to give to the respondents. Besides, the cost of transportation to get to the respondent companies. For digital questionnaire, the valid Internet and prepaid is a must because of the need to call and distribute using WhatsApp, Facebook and e-mail.

The recommendation for future studies should improve the sample of a study, by including all travel agencies in Malaysia, for example, those that applied under Malaysian tourism for outcomes more compact and precise. Thus, the increase of sample will enable deeper the requirement and problems related to travel agencies in adopting e-business. Besides, future studies can also be the focus on different location and other industries. Such research can provide helpful insight for various types of small and medium-sized businesses and factors that influence the decisions made by adoption owners and managers to help SMEs to enter an e-business that can provide a full image of e-business adoption expertise.

Then, the longitudinal study should be undertaken to gain more detail data about how the travel agencies thinking and react with the change in their business activities and qualitative method which can analyzes data through natural language and behavior setting toward customer and business partner in new technology tourism industry nowadays.

\section{References}

[1] Amer, A., Md. Jani, S. H., Ibrahim, I., \& Abd Aziz, N. A. (2019). Brand Preferences in Muslimah Fashion Industries: An Insight of Framework Development and Research Implication. Humanities \& Social Sciences Reviews, 7(1), 209-214.

https://doi.org/10.18510/hssr.2019.7125

[2] Abdullah, A., Thomas, B., Murphy, L., \& Plant, E. (2018). An investigation of the benefits and barriers of e-business adoption activities in Yemeni SMEs. Strategic Change, 27(3), 195-208.

[3] Abdullah, A., White, G., \& Thomas, B. (2016). Conceptualizing a New Stage Model of 
Electronic Business Adoption in Yemeni SMEs.

[4] Abid, A., Rahim, M., Sheepers H. (2011). Experienced Benefits and Barriers of eBusiness Technology Adoption by SME suppliers. [Online] Available: http://www.ibimapublishing.com/journals/CIBIMA/cibima.html [2012-03- 12]

[5] Arowomole, K. A. (2000). Modern business management (Theory and Practice). 1st Edition. Sango-Ota, Ogun State: Ade-Oluyinka Commercial Press.

[6] Aithal, P. S. (2016). A Review on various E-business and M-business models \& Research Opportunities.

[7] Alam, S. S., Khatibi, A., Sim, C. W., \& Haque, A. (2004). Perceived barriers of Ecommerce expansion in the electronic manufacturing companies in Malaysia. International Business and Economics Research Journal, 3, 111-118.

[8] Ali, N., Mat, N., \& Ali, N. (2015). The Conceptual Framework for ICT adoption Model. American Journal of Economics. 5 (2), 148-154. Retrieved from: doi; 10.5923/c.economics.201501.1

[9] Almotamar. (2014) Repaid Growth in e-commerce in Yemen. [Online] Available: http://www.almotamar.net/news/115930.htm [Accessed: 30 September 2018].

[10] Alrousan, M. K. (2015). E-commerce adoption by travel agencies in Jordan (Doctoral dissertation, Cardiff Metropolitan University).

[11] Berita Harian. (2016 October 31). 20 Perjanjian, MOU dimeterai di China. [Online] Available at: https://www.pressreader.com/malaysia/beritaharian5831/20161031/281479275966750. [Accessed: 30 September 2018].

[12] Boyd, S. L., Hobbs, J. E., \& Kerr, W. A. (2003). The impact of customs procedures on business to consumer e-commerce in food products. Supply Chain Management: An International Journal, 8(3), 195-200.

[13] Bright, A. (2012). E-business adoption among small and medium entrprise (SMEs) in Ghana. A case study of business in the Accra Mall.

[14] Buhalis, D., \& Deimezi, O. (2004). E-tourism developments in Greece: Information communication technologies adoption for the strategic management of the Greek tourism industry. Tourism and hospitality research, 5(2), 103-130.

[15] Chaffey, D. (2015). Digital business and e-commerce management. Pearson Education Limited.

[16] Chan, C., \& Swatman, P. (2004). B2B e-commerce stages of growth: The strategic imperatives. Paper presented at the 37th International Conference on System Sciences, Hawaii, USA.

[17] Darren, L., \& Conrad, L. (2009). Entrepreneurship and small business management in the hospitality industry. Jordan Hill, UK: Elsevier Linacre House.

[18] Davison, R. M., Harris, R. W., \& Vogel, D. R. (2005). E-Commerce for CommunityBased Tourism in developing countries. In Proceedings of the 9th Pacific Asia Conference on Information Systems, Bangkok (pp. 1396-1403).

[19] CNN. (2016 July 13). Lonely Planet's Top Asia Spots for 2016. [Online] available: https:/edition.cnn.com/travel/article/lonely-planet-best-in-asia2016/index.htm[Accessed: 20 October 2018].

[20] Davies, A. J. and Garcia-Sierra, A. J. (1999). Implementing electronic commerce in SMEs - three case studies. BT Technology Journal, 17(3): 97-111.

[21] export.gov (2019). Export.gov. Retrieved 17 May 2019 from https://www.export.gov/apex/article2?id=Malaysia-E-Commerce

[22] Faloye, D. O. (2014). The adoption of e-commerce in small businesses: An empirical 
evidence from retail sector in Nigeria. Journal of Business and Retail Management Research, 8(2).

[23] Goode, S. (2002), "Management attitudes toward the World Wide Web in Australian small business", Information Systems Management, pp. 45-8.

[24] Grover,V and P. Ramanlal (1999). Six myths of Information and Markets: Information Technology Networks, Electronic Commerce and battle for consumer surplus. MIS Quarterly 23(4):465-495.

[25] Hajli, N., Sims, J., \& Shanmugam, M. (2014). A practical model for e-commerce adoption in Iran. Journal of Enterprise Information Management, 27(6), 719-730.

[26] Hashim, N. A., \& Abdullah, N. L. (2014). Catastrophe of e-commerce among Malaysian SMEs-Between its perceived and proven benefits. Jurnal Pengurusan (UKM Journal of Management), 42.

[27] Henderson,J.Dooley,F, andAkridge,J. (2000) "Adoption of Ecommerce Strategies for Agribusiness Firms", American Agricultural Economics Association Annual Meeting.A

[28] Heung, V. (2003) "Barriers to implement E-commerce in the travel industry :a practical perspective", International Journal of Hospitality Management, Vol. 22,No. 1, pp.111118

[29] Iddris, F. (2012). Adoption of E-commerce Solutions in Small and Medium-sized Enterprises in Ghana. European Journal of Business and Management, 4 (10), 48-57.

[30] Ivanov, D. (2012). The impact of e-commerce on small-size companies in Sweden.

[31] Jahanshahi, A. A., Zhang, S. X., \& Brem, A. (2013). E-commerce for SMEs: empirical insights from three countries. Journal of Small Business and Enterprise Development, 20(4), 849-865.

[32] Effcoate, J., Chappell, C., \& Feindt, S. (2002). Best practice in SME adoption of ecommerce. Benchmarking: An international journal, 9(2), 122-132.

[33] Kulmala, H.I., Paranko J. and Uusi-Rauva, E., (2002). The Role of Cost Management in Network Relationships. International Journal of Production Economics, 79(1), 3343

[34] Kumar, V., Arif, T., \& Malik, M. B. (2014). Role of ICT in driving e-commerce business in developing countries.

[35] Laudon, K., Traver, C. and Interactive, A. (2009). E-Commerce. 5th ed. Pearson.

[36] Long, C. S., Hii, J. W. S., Kowang, T. O., Fei, G. C., \& Rashid, N. R. A. (2018) Website Quality of the Travel Agencies in Malaysia.

[37] Lun, Y. V., \& Quaddus, M. A. (2011). Firm size and performance: A study on the use of electronic commerce by container transport operators in Hong Kong. Expert Systems with Applications, 38(6), 7227-7234.

[38] MATTA, (2018), Effective Response to Market Dynamics Needed To Draw More Chinese Visitors, Says MATTA. Retrieved from : https:/www.matta.org.my/pressrelease/12333-effective-response-to-market-dynamics-needed-to-draw-more-chinesevisitors-says-matta

[39] MasterCard Crescenting (2017). Global Muslim Travel Index (GMTI) 2017. Retrieved from: https:/www.crescentrating.com/reports/mastercard-crescentrating-globalmuslim-travel-index-gmti-2017.html.

[40] Musawa,M., and Wahab, E. 2012 "The adoption of electronic data interchange (EDI) technology by Nigerian SMEs: A conceptual framework" , Journal of Business Management and Economics, Vol. 3, No. 2, pp. 55-68.

[41] Meeting of the OECD council at Ministerial Level (2017 June 7-8): Enhancing the 
contribution SMEs in Global and Digital Economy:OECD.[PDF file]. Retrieved from https://www.oecd.org/mcm/documents/C-MIN-2017-8-EN.pdf.

[42] Martin, L. M., \& Matlay, H. (2001). "Blanket" approaches to promoting ICT in small firms: some lessons from the DTI ladder adoption model in the UK. Internet research, 11(5), 399-410.

[43] Mazzarol,T. (2015): SMEs engagement with e-commerce, e-business and emarketing, Small Enterprise Research, DOI: 10.1080/13215906.2015.1018400.

[44] Olusegun, A. I. (2012). Is small and medium enterprises (SMEs) an entrepreneurship? International Journal of Academic Research in Business and Social Sciences, 2(1), 487.

[45] Odhiambo, O. P. (2013). E-commerce adoption among micro, small and medium sector in Nairobi County, Kenya (Doctoral dissertation, Kenyatta University).

[46] Park, C. (2007). A Content Analysis of Travel Agency Websites in Korea. Asia Pacific. Journal of Tourism Research, 7(1), 11-18. https://doi.org/10.1080/10941660208722105

[47] Peng,C.Y. and Trappey, C.V. (2005). "Internet and e-Commerce adoption by the Taiwan semiconductor industry", Journal of Industrial Management \& Data Systems, vol. 105 no. 4 , pp. $476-490$.

[48] Poon, S. (2000), "Business environment and Internet commerce benefit - a small business perspective", European Journal of Information Systems, Vol. 9, pp. 72-8

[49] Rainer, R. K., Cegielski, C. G., Splettstoesser-Hogeterp, I., \& Sanchez-Rodriguez, C. (2013). Introduction to information systems. John Wiley \& Sons.

[50] Rahman, N. M. N., Sulaiman, Z., Hamid, A. B. A., \& Khalifah, Z. (2013). The Implementation of E-commerce Application in Bumiputera Small and Medium Enterprises (SMEs) in Malaysia. IJAME

[51] Shaharuddin, N.S., Rahman, A.A., Aziz, Y.A.,\& Kassim ,S.(2018). An assessment of web technologies \& E-business adoption among SMEs travel agencies in Malaysia, Journal of Academia UiTM Negeri Sembilan Vol.6, Issue 1 (2018) 89-96.

[52] Saunders, M., Lewis, P., \& Thornhill, A. (2016). Research Methods For Business Students (7th ed.). Harlow: Pearson Education Limited.

[53] Sin, K., Osman, A., Haji-Othman, Y. and Safizal, M. (2015). E-Commerce Adoption among Small and Medium Enterprises (SMEs) in Northern State of Malaysia. MJSS, vol. 6, no. 5, pp. 37-43.

[54] SME Corp. Malaysia. (2015). SMEs Definition. Retrieved from http://www.smecorp.gov.my/index.php/en/policies/2015-12-21-09-09-49/smedefinition

[55] Steinfield, C., LaRose, R., Chew, H. E., \& Tong, S. T. (2012). Small and medium-sized enterprises in rural business clusters: the relation between ICT adoption and benefits derived from cluster membership. The Information Society, 28, 110-120.

[56] Stockdale, R., \& Standing, C. (2004). Benefits and barriers of electronic marketplace participation: an SME perspective. Journal of Enterprise Information Management, 17(4), 301-311.

[57] Sparling, L., M., \& Toleman A. C. (2007). SME adoption of e-commerce in the central Okanagan region of Canada, Proceedings of the 18th Australasian Conference on Information Systems

[58] The Sun daily. (2018, September 12). Low digital adoption among businesses [Online]: https://www.thesundaily.my/archive/low-digital-adoption-among-businessesIUARCH577875. [Access 17 November 2018]

[59] The Star (2018 August 20). Opportunities in e-commerce. online, Retrieved from https://www.thestar.com.my/business/smebiz/2018/08/20/opportunities-in-ecommerce/. 
[Accessed :19 November 2018].

[60] The Star. (2017 March 16).E-commerce adoption rate among SMEs to grow to $50 \%$ by 2020 [Online] Available at: https://www.thestar.com.my/business/businessnews/2017/03/16/ecommerce-adoption-rate-among-smes-to-grow-to-50-by2020/.[Accessed: 30 September 2018].

[61] Tan, J., Taylor, M., \& Murphy, A. (2004). SMEs and e-business. Journal of small business and enterprise development, 11(3), 280-289.

[62] Timmers, P. (1998). Business Models for Electronic Markets, Journal on Electronic Market, 8(2), P.3-8.

[63] Tan, Z.A. and W.Ouyang (2010), Global and National factors affecting E-commerce Diffusion in china. Journal, Zhejiang University.

[64] The Best Shopping Cities in The World - Ranked | Explore by Expedia. (2016). Retrieved from https://www.expedia.co.uk/explore/the-best-shopping-cities-in-theworld-ranked.

[65] The Winners List: The 2016 Travvy Awards Presented by Dream Vacations. (2016). Retrieved from https://www.travelpulse.com/news/travel-agents/the-winners-list-the2016-travvy-awards-presented-by-dream-vacations.html

[66] Turban,E., Outland, J., King, D., Lee, J. K., Liang, T. P., \& Turban, D. C. (2017). Electronic commerce 2018: a managerial and social networks perspective. Springer.

[67] Utusan Borneo. (2017, June 29). Kerajaan promosi e-dagang bantu usahawan PKS.,[Online] available at: https://www.utusanborneo.com.my/2017/06/29/kerajaanpromosi-e-dagang-bantu-usahawan-pks [Acesses: 29 october 2018].

[68] Wong, C. 2013. eCommerce MILO: The Ultimate Guide to E-Commerce Statistics of Southeast Asia \& Malaysia. [online] eCommerce MILO. Available at: http://www.ecommercemilo.com/2013/08/ecommercestatistic-southeastasiamalaysia.html [Accessed 12 Nov. 2018].

[69] World Travel Awards 2016 Australasia Winners. (2016). Retrieved from: https://www.worldtravelawards.com/winners/2016/australasia 